MIDPI

sciforum
MOL2NET, International Conference Series on Multidisciplinary Sciences

06. MODECO-05: Molec. Diversity \& Ecosystems, Puyo, Ecuador-Porto, Portugal-Paris,

\title{
Hydroponic green forage an alternative for feeding animals of zootechnical interest on a small and medium scale
}

\author{
Willan Caicedo ${ }^{1,2}$, Carlos Fernández ${ }^{1}$, Mishel Cujilema ${ }^{1}$
}

${ }^{1}$ Facultad de Ciencias de la Tierra, Universidad Estatal Amazónica, Puyo, Pastaza, Ecuador

${ }^{2}$ Granja Agropecuaria Caicedo, Puyo, Pastaza, Ecuador

\begin{tabular}{|c|c|}
\hline Graphical Abstract & $\begin{array}{l}\text { Abstract. } \\
\text { The cost of feeding represents the largest item in } \\
\text { the production of animals of zootechnical } \\
\text { interest, in this sense, recent research has focused } \\
\text { on the use of alternative foods that can compete } \\
\text { with conventional raw materials in quantity, } \\
\text { quality and price. The objective of this work was } \\
\text { to analyze scientific information on the current } \\
\text { situation of the use of hydroponic green forage } \\
\text { for feeding animals of zootechnical interest on a } \\
\text { small and medium scale. The present } \\
\text { investigation was exploratory and was based on } \\
\text { an updated bibliographic compilation. The } \\
\text { introduction of hydroponic green forage of } \\
\text { sorghum, corn, wheat and barley in the diet of } \\
\text { pigs, poultry, rabbits, guinea pigs, allows to } \\
\text { reduce the cost offeeding, it is easy to produce, it } \\
\text { is grown all year round, it requires little space, it } \\
\text { presents high nutrient utilization coefficients. In } \\
\text { addition, it allows to achieve a significant } \\
\text { increase in the increase of weight, consumption, } \\
\text { weight gain and feed conversion of the animals. } \\
\text { The production of hydroponic green forage is an } \\
\text { easy technique to apply and does not require a } \\
\text { high initial investment for its implementation in } \\
\text { the feeding systems for animals in small and } \\
\text { medium scale farms. } \\
\text { Key words: Alternative feeding, feed cost, animal } \\
\text { production, productive performance. }\end{array}$ \\
\hline
\end{tabular}




\section{Introduction}

The recent world crisis and the high price of animal feed forces nutritionists to investigate and incorporate non-traditional ingredients into the diet of animals, such is the case of hydroponic green forage (HGF) (De Luca et al., 2021). The application of this technique allows to be more competitive in the market since the costs in feeding are reduced. HGF is an efficient and suitable technology for small and medium agricultural producers to expand their possibilities and opportunities to produce HGF as a supplement, minimizing dependence on the use of balanced feed. The production of HGF is carried out in a sustainable way, optimizing the economic resource, soil, water and space.

The implementation and supply of HGF, as animal feed, allows to achieve a significant increase in weight, feed conversion, productive performance and meat production, since it has excellent nutritional quality and nutritional value, vitamins such as $\mathrm{A}, \mathrm{B}$ and $\mathrm{E}$ that allow reduce the diseases that affect most species of zootechnical interest. In addition, they have high digestibility, palatability and acceptance by the animals (Romero y Rodriguez, 2009).

According to Saguilán et al. (2020), for the elaboration of HGF it is used as a specific raw material; seeds of corn, sorghum, oats and wheat, which have a germination power that ranges between $85-95 \%$. However, it should be emphasized that in order to obtain an excellent production of HGF, the requirements of the crop must be met and thus avoid economic losses.

The objective of this work was to analyze scientific information on the current situation of the use of hydroponic green forage for feeding animals of zootechnical interest on a small and medium scale.

\section{Materials and Methods}

The research was based on the use of the documentary exploratory method, since a systematic search was carried out in databases of international prestige.

\section{Results and Discussion}

The use of hydroponic green forage constitutes a novel alternative of feeding for farm animals, which allows to reduce the cost of the feed since it is easy to produce, it is grown all year round, it requires little space, and others, it presents high utilization coefficients of nutrients in pigs, rabbits, guinea pigs, poultry and cattle.

The HGF is the result of the germination process of cereals, under controlled environmental conditions of light, temperature and humidity in a period of 8-15 days, without the use of soil and under a greenhouse, allowing the production of food for animals under any climatic condition. throughout the year and in large quantities, since $5 \mathrm{~kg}$ of seed $/ \mathrm{m}^{2}$ yield 40 to $50 \mathrm{~kg}$ of fresh forage per $\mathrm{m}^{2}$ of tray.

However, to guarantee that the forage production is optimal and of quality, the selection and management of the seed must be considered essentially taking into account that the material used has $90 \%$ viability, being whole without ruptures that allow penetration and propagation. of pathogens and clean without trace of any toxic product.

Table 1 shows the main advantages and disadvantages of HGF production and supply to animals. 
Table 1. Advantages and disadvantages of HGF

\begin{tabular}{lll}
\multicolumn{1}{c}{ Advantages } & \multicolumn{1}{c}{ Disadvantages } \\
\hline$-\quad$ Production scheduled according to the & - & Disinformation and lack of training for \\
needs of the animals. & producers. \\
$-\quad$ It can be produced in all climates and & - & Establish a specialized work routine. \\
times of the year. & - & Investment costs for acquiring tools for \\
$-\quad$ Appetizing to animals due to its high & sprouting. \\
nutritional content. & - & Minimum amount of dry matter and \\
High production in confined spaces, low & fiber. \\
production costs per feed and reduced & &
\end{tabular}

Source: Chavaría-Torrez and Castillo- Castro (2018)

If the forage production occurs under a suitable temperature and relative humidity plus the use of quality seeds, yields of 10-12 times the weight of the seed is achieved and a fresh food will be obtained, with a height of 25 to $30 \mathrm{~cm}$ in a period of 7-10 days. The biomass obtained is compared with an abundant root cushion of leaves, stem and germinated and non-germinated seeds in the form of a food block that can be supplied to the animal, freshly harvested or within 2-3 days of being harvested, either chopped, shredded or minced. However, if HGF is stored for 2-3 days or longer, the forage will lose nutritional quality. The conversion from seed to grass is one $\mathrm{kg}$ of seed per seven kg of forage (Juárez-López et al., 2013).

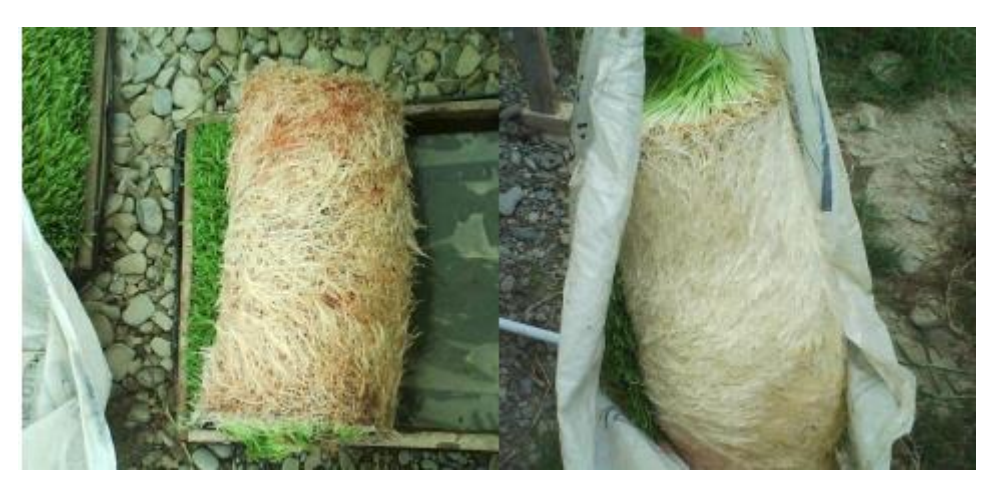

Figure 1. Forage mattress

Source: Vargas (2015)

The hydroponic green corn forage constitutes the most investigated raw material for animal feeding, it has high availability and digestibility, and a lower cost of seed acquisition compared to wheat and oats 
(Adebiyi et al., 2018). Table 2 shows the productive performance of pigs fed with green hydroponic corn forage.

Table 2. Productive performance of pigs fed with green hydroponic corn forage

\begin{tabular}{|c|c|c|c|c|c|c|c|}
\hline $\begin{array}{l}\text { Inclusion } \\
\text { levels, \% }\end{array}$ & $\begin{array}{c}\text { Treatment } \\
\text { days }\end{array}$ & $\begin{array}{c}\text { Initial } \\
\text { weight, } \\
\text { kg } \\
\end{array}$ & $\begin{array}{c}\text { Final } \\
\text { weight, } \\
\text { kg }\end{array}$ & $\begin{array}{c}\text { Feed } \\
\text { conversion } \\
\text { kg/kg } \\
\end{array}$ & $\begin{array}{c}\text { Weight } \\
\text { gain } \\
\text { day, kg }\end{array}$ & $\begin{array}{c}\text { Feed } \\
\text { consumption } \\
(\mathrm{kg} / \mathrm{day})\end{array}$ & References \\
\hline 15 & $120^{\mathrm{a}}$ & $9.63^{\mathrm{a}}$ & $42.05^{\mathrm{a}}$ & $3.40^{\mathrm{a}}$ & $0.38^{\mathrm{a}}$ & $1.22^{\mathrm{a}}$ & \multirow{3}{*}{$\begin{array}{l}\text { Saguilán et } \\
\text { al. }(2020)^{\text {a }}\end{array}$} \\
\hline 30 & $120^{\mathrm{a}}$ & $12.88^{\mathrm{a}}$ & $49.69^{\mathrm{a}}$ & $2.95^{\mathrm{a}}$ & $0.43^{\mathrm{a}}$ & $1.20^{\mathrm{a}}$ & \\
\hline 45 & $120^{\mathrm{a}}$ & $12.38^{\mathrm{a}}$ & $55.05^{\mathrm{a}}$ & $2.52^{\mathrm{a}}$ & $0.51^{\mathrm{a}}$ & $1.19^{\mathrm{a}}$ & \\
\hline 50 & $120^{\mathrm{b}}$ & $12.0^{\mathrm{b}}$ & $18.00^{\mathrm{b}}$ & $2.60^{\mathrm{b}}$ & - & - & \multirow[b]{2}{*}{$\begin{array}{c}\text { Rivera y } \\
\text { Díaz } \\
(2017)^{\mathrm{b}} \\
\end{array}$} \\
\hline 70 & $120^{\mathrm{b}}$ & $12.0^{\mathrm{b}}$ & $16.50^{\mathrm{b}}$ & $3.46^{\mathrm{b}}$ & - & - & \\
\hline
\end{tabular}

\section{Conclusions}

The production of hydroponic green forage is an easy technique to apply and does not require a high initial investment for its implementation in the feeding systems for animals in small and medium scale farms.

\section{References}

- Adebiyi, O. A., Adeola, A.T., Osinowo, O.A., Brown, D. \& NG'Ambi, J.W. 2018. Effects of feeding hydroponics maize fodder on performance and nutrient digestibility of weaned pigs. Appl. Ecol. Environ. Res., 16(3): 2415-2422

- Chavaría-Torrez, A. \& Castillo-Castro, S. 2018. El forraje verde hidropónico (FVH), de maíz como alternativa alimenticia y nutricional para todos los animales de la granja. Revista Iberoamericana de Bioeconomía y Cambio Climático, 4(8): 1032-1039

- De Luca, V. 2021. Forraje verde hidropónico: forraje verde siempre. Rev. Med. Vet., 102(1): 1117

- Juárez-López, P., Morales-Rodriguez, H., Sandoval-Villa, M., Gómez-Danés, A., Cruz-Crespo, E., Juárez-Rosete, C., Aguirre-Ortega, J., Santiago, A. \& Ortiz-Catón, M. 2013. Producción de forraje verde hidropónico. Revista Fuente Nueva Época, 4(13): 18-22

- Rivera, A. \& Díaz, E. 2017. Evaluación de cultivos hidropónicos de maíz y sorgo para la alimentación de porcinos en la etapa de levante y pre. ceba en el Departamento de Bolívar, Finca: La Conquista, corregimiento de Pasacaballos, vía al Municipio de Rocha (Tesis de pregrado). Universidad Nacional Abierta y a Distancia, Cartagena de Indias, Colombia.

- Romero, N. \& Rodríguez, J. 2009. Evaluación de dos niveles de reemplazo de ingredientes en dietas tradicionales por forraje hidropónico de maíz (Zea mays L) para cerdos confinados en la fase de crecimiento y acabado. Escuela Superior Politécnica del Litoral, Guayaquil, Ecuador.

- Saguilán, P., Aguirre, H., Martínez-Martínez, R., Vásquez, A., Peralta, M. \& Monter, M.A. 2020. Forraje verde hidropónico en dietas de cerdos en crecimiento en Pinotepa Nacional, Oxaca. Revista Mexicana de Ciencias Agrícolas, 24: 247-253 
- Vargas, A. 2015. Rendimiento de Sorgo (Shorgum bicolor) y cebada (Hordeum vulgare) bajo tres densidades de siembra como forraje verde hidropónico (Tesis de pregrado), La Paz, Bolivia. 